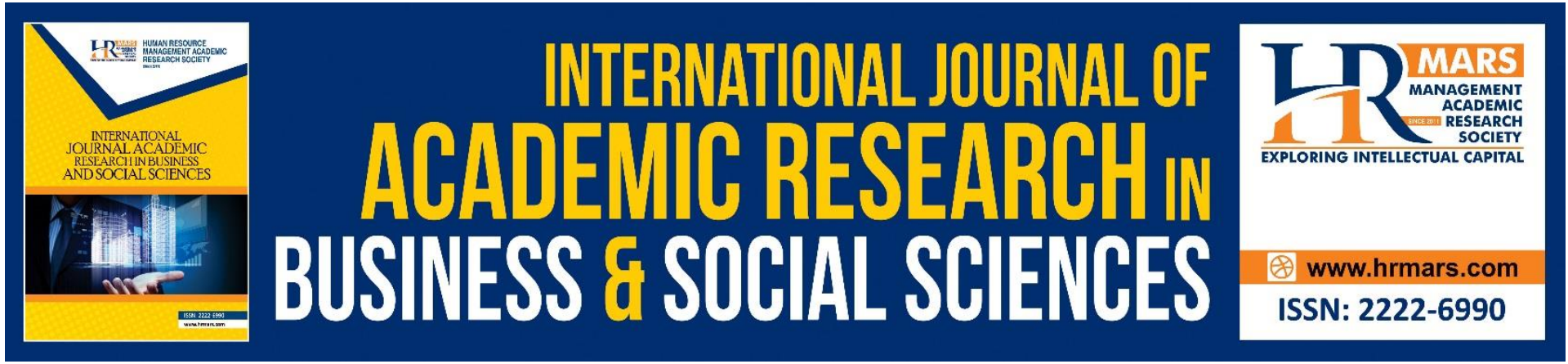

\title{
Assessment on Factors Affecting Asset Management Performance in Malaysian Government Agencies: A Concept Paper
}

Ahmad Tajudin, I. K. Norziaton, Aida Hazlin Ismail

To Link this Article: http://dx.doi.org/10.6007/IJARBSS/v11-i7/10531

DOI:10.6007/IJARBSS/v11-i7/10531

Received: 12 May 2021, Revised: 19 June 2021, Accepted: 05 July 2021

Published Online: 28 July 2021

In-Text Citation: (Tajudin et al., 2021)

To Cite this Article: Tajudin, A., Norziaton, I. K., \& Ismail, A. H. (2021). Assessment on Factors Affecting Asset Management Performance in Malaysian Government Agencies: A Concept Paper. International Journal of Academic Research in Business and Social Sciences, 11(7), 736-751.

Copyright: (c) 2021 The Author(s)

Published by Human Resource Management Academic Research Society (www.hrmars.com)

This article is published under the Creative Commons Attribution (CC BY 4.0) license. Anyone may reproduce, distribute, translate and create derivative works of this article (for both commercial and non-commercial purposes), subject to full attribution to the original publication and authors. The full terms of this license may be seen at: http://creativecommons.org/licences/by/4.0/legalcode

Vol. 11, No. 7, 2021, Pg. 736 - 751

Full Terms \& Conditions of access and use can be found at http://hrmars.com/index.php/pages/detail/publication-ethics 


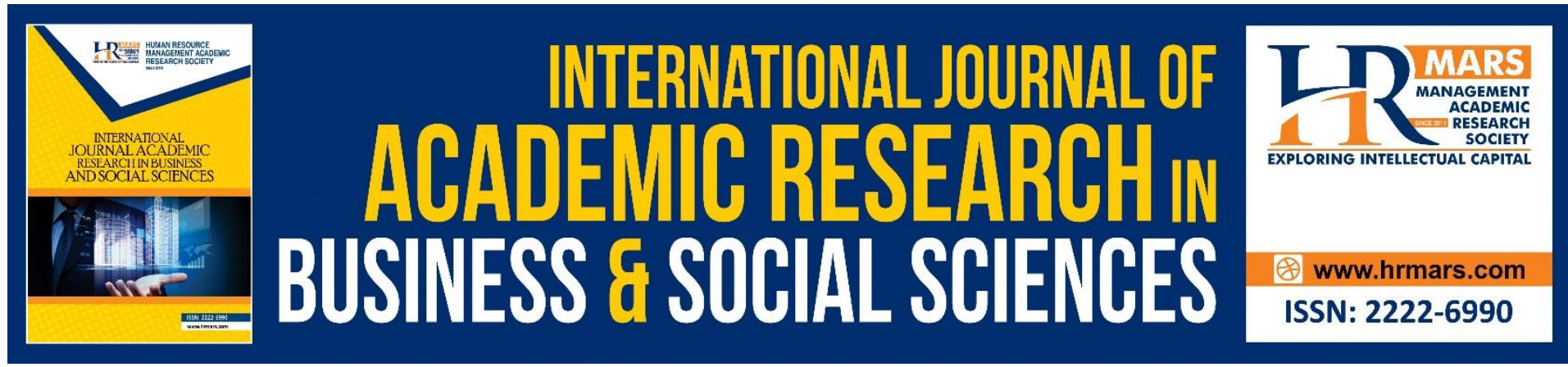

\title{
Assessment on Factors Affecting Asset Management Performance in Malaysian Government Agencies: A Concept Paper
}

\author{
Ahmad Tajudin \\ Accountant General Department, Putrajaya \\ I. K. Norziaton, Aida Hazlin Ismail \\ Faculty of Accountancy, Universiti Teknologi Mara Shah Alam
}

\begin{abstract}
Asset management is a "joined in" organisation activities to realise value from its controlled resource. Asset management evolved from simple maintenance, which was treated as a "necessary evil" in the 1970s, to the current position that is the core functions of organisational strategies. In Malaysia, the government is committed to enhancing asset management quality to ensure it is managed in a systematic, holistic, and sustainable manner; thus, policies and procedures regarding asset management have been issued since 1967 . However, the Auditor- General Report found out that most government agencies are unable to manage their assets efficiently. This study focuses on analysing factors affecting asset management performance in government agencies in Malaysia. This study will look at the issues commonly raised by the Auditor-General Report, particularly on asset management, and identify the factors affecting asset management performance. The conceptual part consists of an extensive search and analysis of secondary sources of information through references and reviews of academic articles, Auditor-General's Report, news, and publications related to asset management. The literature review's analysed data indicate that three issues can be underlined: ineffective maintenance practice, misused and theft of government assets, and inadequate asset management knowledge. Accordingly, to clarify the factors leading to the said problems, a conceptual structure has been proposed based on previous studies. The identified factors leading to asset management issues in the public sector are maintenance practice, asset misappropriation, and training policy. This study has also analysed the gaps in past studies regarding asset management research. This concept paper provides a valuable addition to the current knowledge base, particularly on how factors affecting asset management performance in government agencies and hindering the government from delivering an efficient service to the public. The implications and recommendations for future research are also discussed.
\end{abstract}

Keywords: Asset Management, Public Sector, Maintenance Practice, Assets Misappropriation, Training Policy 


\section{Introduction}

Asset management (AM) is a strategic and integrated process involving various disciplines, such as engineering, operating, management, and maintenance, to gain the greatest benefit lifetime and the assets' returns (Amadi-Echendu et al., 2010; Laue et al., 2014). AM needs participation from different areas, primarily human activities, to manage individuals who control assets and incorporate asset-related policies in the operational and organisational frameworks, particularly asset maintenance (Nel \& Jooste, 2016). The importance of AM has been discussed, developed, and taken into account for several decades. AM landscape is not considered a new discipline, but it is a part of its constant evolution (Amadi-Echendu et al., 2010; Wijnia, 2016).

Many countries have reformed their AM; the government of the United Kingdom, New Zealand, and Australia, were among the early countries that started to move into the formal management of physical assets (Naief, 2018). Similarly, the government of Malaysia is committed to review and enhance the quality of AM to ensure it is managed in a systematic, holistic, and sustainable manner because vast investment has been made in developing and building assets. The government provided assets to enhance its citizens' quality of life; thus, it is an essential instrument for the government in delivering services either directly or indirectly (GAMP, 2009).

However, the Auditor-General Report found out that most government agencies are unable to manage their asset efficiently. Wastefulness, extravagance, and mismanagement have been detected, indicating that the public money had not been wisely spent. Asset management performance is also ranked the lowest compared to other elements in the financial management accountability index for five consecutive years (2014-2018) except in 2016. It implies that AM performance in the public sector is weak compared to other elements audited. Al Marzooqi et al (2019) opine that improving AM performance is a complex process and influenced by several factors, including employees training, effective maintenance practice, and workplace culture

The government needs to manage the assets effectively to ensure the quality of public service delivery and increased public resources (Backer \& Yusoff, 2015; Rasolonjatovo et al., $2015)$ to hinder government fund wastage. The wastage of government funding can happen because of ineffective AM and asset misappropriation (Haron et al., 2015).. According to the PwC report 2020, the internal fraud perpetrator, which is asset misappropriation fraud, is the second-highest serious or disruptive incident in Malaysia. Thus, the government needs to provide more training to their employees to increase public service quality (Elnaga \& Imran, 2013) and promote ethical behaviours to safeguard government assets.

A study by Abdullah and Muhammad (2020) found that the government servant raised the issue of lack of training on AM by government agencies. The lack of training caused employees to have inadequate knowledge and skills in asset management and failed to comply with the loss procedure (Auditor General's Report, 2019). Mazlan and Mohammed (2008), and Backer and Yusoff (2015) suggest that government agencies should provide adequate training to their employees to enhance AM knowledge because training and development programmes play an important role in achieving AM strategies and goals (Kriege et al., 2016).

One of the AM objectives is to allow organisations to create, enhance, and/or sustain a resource with corporate governance values to ensure the AM paradigm shift much broader than the maintenance scope (Amadi-Echendu, 2004). Ensuring the infrastructure and equipment are in good condition is imperative. The improper maintenance has caused 
recurring damage to government equipment (Auditor General's report, 2017); hence, affecting the service delivery.

Various issues of asset management have occurred in government agencies, such as ineffective maintenance practice, misused and theft of government assets, and inadequate knowledge of the AM procedure, affecting AM performance's effectiveness, efficiency, and economics in government agencies (Buang, 2011).

This study aims to explore and identify factors contributing to these issues that have been studied extensively by previous literature. The study's outcomes would then allow government agencies to take appropriate measures to improve AM performance because AM's effectiveness plays an increasingly important role in optimising government performance. This study is conducted by reviewing several articles and exploring some previous studies on asset management and the Auditors-General Report for 2014 to 2019.

\section{Literature Review \\ Asset Management}

Asset management can be defined as the "joined in" activities of an organisation to realise value from its controlled resource. The United States Department of Transport described $\mathrm{AM}$ as a comprehensive asset maintenance process, upgrading and operating with cost-effectiveness. In order words, AM can be seen as a combination of engineering fundamentals with organisational processes and economic theory.

AM comprises several processes of maintaining an asset's function to ensure it performs effectively and cost and risk control to accomplish the objectives and ensure service delivery by agencies (TAMM, 2009). Managing the asset allows an organisation to create, enhance, and sustain its business. The critical aspect of managing the assets is to maintain the asset so that its function remains. Schraven et al. (2011) indicate that establishing alignment between assets objectives, situation and intervention, the formulation of assets objectives, and managing multiple actors with different interests are the key challenges to achieve effective AM. The government need to develop sufficient AM policies (Hanis et al., 2010) to ensure AM effectiveness. Effective AM allows an organisation to can increasing the economic productivity (Sara et al., 2021) and allow the organisation to save money for long term (Mastroianni et al., 2021).

Generally, AM performance is influenced by adequate resources, employee competencies, acceptable practices, partnership with external service providers, and a supportive workplace environment. Ismail et al. (2019) found that employees' knowledge and internal control are essential to AM practices in a government department, while organisational culture and information systems did not influence AM practice. A good AM creates the best possible use of resources and customer support and efficiency, align with a balanced financial goal (Too, 2010). The achievement of good AM depends on the availability of appropriate, qualitative, and timely information on assets as well as extensive knowledge of asset managers (Hastings, 2015).

The focus of AM is on the efficient management of an asset's life cycle, from acquisition to use, maintenance, and disposal. The emphasis is not on the revenue it might create for an organisation but on results, risks, and costs to get the best solutions.

\section{Overview of Asset Management Guidelines in Malaysia Public Sector}

The government of Malaysia has issued several guidelines to ensure a systematic approach to AM and comprehensive asset procedure, as shown in Table 1. Effective AM 
allows government agencies to deliver service efficiently as part of the NPM public sector reforms.

Table 1: List of Procedures and Circulars Issued by Government (Source: Buang, 2011)

\begin{tabular}{ll}
\hline Year & Procedure/Circular \\
\hline 1967 & $\begin{array}{l}\text { The Factories And Machinery Act outlined safety and health } \\
\text { standards requirements in } 1967 .\end{array}$ \\
\hline 1974 & $\begin{array}{l}\text { Rules were circulated for the maintenance of buildings, public } \\
\text { roads, sewage systems, and the role and responsibilities of the } \\
\text { Public Works Department. }\end{array}$ \\
\hline 1992 & Guidelines For Total Quality Management In The Public Service. \\
\hline 1995 & $\begin{array}{l}\text { General Circular Letter No. } 2 \text { on the "Maintenance Management } \\
\text { - Establishment of Planned Maintenance System" was issued to } \\
\text { enhance the public sector's maintenance management system. }\end{array}$ \\
\hline 2007 & $\begin{array}{l}\text { Treasury Circular No. } 5 \text { provided guidelines for the management } \\
\text { of moveable assets. }\end{array}$
\end{tabular}

$2009 \quad$ General Circular No. 1 outlining the government's policy and principle on total asset management.

The government is committed to improving AM because it is used to measure the performance of the financial management of government agencies based on the financial management accountability index. The government has been actively taken the initiative to issue procedures about the AM since 2007 through Treasury Circular No 5/2007.

Previously there was no single guidelines or standard on the complete procedure regarding $A M$ because guidelines on government $A M$ are scattered in several separate documents, including Treasury Instructions (APS), Treasury Guidelines - Store Management Procedures (PP-TPS), Treasury Circulars (PP), Treasury Circulars (SPP) and General Circular. This situation causes employees unable to manage assets efficiently and timely because they need to refer to various procedures.

To strengthen the AM, the government had to launch the Government Asset Management Policy (GAMP) and Total Asset Management Manual (TAMM) in 2009. This first comprehensive AM policy outlined the direction, principles, and strategies for implementing AM that must be adhered to by every government agency. GAMP requires the asset to be managed in a comprehensive and integrated manner, including planning, creation, usage, maintenance, inspection, disposal, and write-off procedures to ensure that the assets are in good condition, safe to use, cost-effective, and long-lasting. There has been no other procedure on asset management in the public sector issued after 2009. Thus, the Ministry of Works has called for a review on the GAMP to determine whether all government assets are systematically, holistically, and sustainably managed (Kannan, 2018).

GAMP requires a comprehensive and efficient $A M$, including the preparation, development, usage, maintenance, review, disposal, and write-off procedures to ensure the assets were in good condition, safe and cost-effective to use. The AM policy, strategy, plan, 
and objectives represent the AM system's planning environment and translate the goals and mission from its strategic plan. These are implemented in the government agencies through the AM lifecycle activities.

\section{Related Literature and Research Gaps}

Past literature on asset management was conducted from different dimensions. However, the studies' findings were inconsistent, and gaps were found in the studies, as shown in Table 2. In the context of Malaysia, studies on asset management are still low (Garramone et al., 2020). Most of the studies were conducted in developed countries, of which the factors may not apply to Malaysia. There has been very limited discussion on the impact of asset misappropriation on asset management as well. Moreover, none of the studies had looked into the relationships between maintenance practice, asset misappropriation, and training policy against the AM performance (Al Marzooqi et al., 2019; Ismail et al., 2019; Majid et al., 2014).

Table 2: Dimensions and gaps of studies on asset management performance

\begin{tabular}{|c|c|c|c|}
\hline No & Author, Year & Dimensions & Gaps \\
\hline 1. & $\begin{array}{l}\text { Kaganova } \\
\text { Amoils (2020) }\end{array}$ & $\begin{array}{l}\text { a. Austerity measures } \\
\text { b. Performance } \\
\text { management } \\
\text { c. Technology and } \\
\text { business operations } \\
\text { d. Environmental } \\
\text { sustainability } \\
\text { f. Political and } \\
\text { ideological agendas }\end{array}$ & $\begin{array}{l}\text { A study conducted in broad } \\
\text { review and not measure specific } \\
\text { aspects of asset management. }\end{array}$ \\
\hline 2. & $\begin{array}{l}\text { Sanjaya and Utama } \\
\text { (2020) }\end{array}$ & $\begin{array}{l}\text { a. Organisational } \\
\text { b.Information system } \\
\text { c. Strategic planning } \\
\text { d.Asset Optimisation }\end{array}$ & $\begin{array}{l}\text { A study conducted in one district } \\
\text { and the empirical test is } \\
\text { undertaken only on the internal } \\
\text { factor. }\end{array}$ \\
\hline 3. & Ismail et al. (2019) & $\begin{array}{l}\text { a. Employees' } \\
\text { Knowledge } \\
\text { b. Internal Control } \\
\text { c. Organisational } \\
\text { Culture } \\
\text { d. Information System }\end{array}$ & $\begin{array}{l}\text { Lack of empirical study of the } \\
\text { factors for effective asset } \\
\text { management. Little discussion of } \\
\text { the impact of internal control on } \\
\text { asset misappropriations. }\end{array}$ \\
\hline 4. & $\begin{array}{l}\text { Al Marzooqi et al. } \\
(2019)\end{array}$ & $\begin{array}{l}\text { a. Resource } \\
\text { b. Employee } \\
\text { Competency } \\
\text { c. Practice } \\
\text { d. Partnership } \\
\text { e. Training Workplace } \\
\text { f. } \quad \text { Environment }\end{array}$ & $\begin{array}{l}\text { A study conducted explicitly in a } \\
\text { developed country; the results } \\
\text { might be different in a } \\
\text { developing country. } \\
\text { The study only explored the } \\
\text { factors required for managing } \\
\text { assets within the utilisation } \\
\text { stage and did not cover other } \\
\text { lifecycle stages, such as planning, } \\
\text { designing, acquisition, and } \\
\text { disposal. }\end{array}$ \\
\hline
\end{tabular}




\begin{tabular}{|c|c|c|}
\hline 5. $\quad$ Naief (2017) & $\begin{array}{l}\text { a. External } \\
\text { environment } \\
\text { b. Internal } \\
\text { environment } \\
\text { c. Options formulation } \\
\text { d. Options evaluation } \\
\text { e. Programme } \\
\text { formulation } \\
\text { f. Portfolio alignment } \\
\text { g. Implementation }\end{array}$ & $\begin{array}{l}\text { The study using a qualitative } \\
\text { approach and interviews with } \\
\text { limited interviewees in a } \\
\text { developed country. The result } \\
\text { might not be generalised and be } \\
\text { used in another country. }\end{array}$ \\
\hline
\end{tabular}

\section{Asset Management Performance}

Performance measurement is a construct used by an organisation to measure the result of activities conducted. Performance can be regarded as a set of processes that enable interested parties to take effective action to develop a productive and efficient organisation in the future (Lebas \& Euske, 2007). In order to take such actions, decision-making is based on reliable, valid, and relevant sources of information. Management is obsessed with performance, trying to measure every aspect of operation (Neely, 2007), resulting in an unnecessary focus on irrelevant processes. Even though organisations have been managing their assets, AM is becoming more challenging than in the previous decade because AM has evolved.

In a competitive landscape, it is important to manage assets effectively and efficiently to achieve optimal returns and gain competitive advantages. It cannot be done by only considering the assets' entire lifetime and all associated costs and maintenance; instead, AM should not be viewed as different concerns (Campbell \& Reyes, 2014).

AM's performance is a construct used by the organisation to measure the organisation's outcomes from asset management activities conducted based on the concept of 3Es (economy, efficiency, and effectiveness) (Buang, 2011). Efficiency and effectiveness analysis is based on the relationships between the inputs, outputs, and outcomes. Mihaiu et al. (2010) stated that effectiveness is an indicator based on the outcomes' ratio achieved to the one configured. At the same time, efficiency is a measure obtained by disclosing the results of the efforts made. Public spending efficiency indicates a relationship between the economic and social consequences of introducing any activities and the effort made to fund them.

\section{Factors Affecting Asset Management Performance Maintenance Practice}

Asset management involves systematic and coordinated activities and practices through which an organisation ideally and sustainably oversees its assets and asset systems (Alfatih et al., 2015). Jooste and Page (2004) asserted that the implementation of maintenance management results in sustainable assets. Thus, to ensure assets' sustainability, AM should seek to move away from traditional maintenance practices (Amadi-Echendu, 2004). Effective maintenance management may reduce the life cycle cost while ensuring the efficient use of the assets.

Maintenance practice can be defined as a set of activities or practices that includes inspections and identification of faults to oversees assets based on the maintenance 
strategies: Predictive, Preventive, and Corrective ( Ratnayake \& Markeset, 2010). The Preventive Maintenance Strategy aims to evaluate a sequence of reviews, replacements, and part revisions with a fault rate frequency. Preventive maintenance addresses issues that occur due to the wear and tear of assets. It is performed before asset failure, decreases potential failure probability, and increases reliability.

On the other hand, predictive maintenance monitors the asset's efficiency to predict when maintenance will be carried out. This approach provides cost advantages for proactive maintenance and allows for easy scheduling of maintenance operations and eliminating unintended failures. It might be the most cost-effective maintenance solution (Kirubakaran \& llangkumaran, 2016).

Corrective maintenance is undertaken when failures occur and view as a cost-saving strategy, which could cause serious harm to properties, infrastructure, people, and the environment (Fouladgar et al., 2012; Ratnayake \& Markeset, 2010). The key advantage of corrective maintenance is that the activities are only carried out when the system is broken down.

The implementation of the types of maintenance chosen by the organisation influence the performance of AM. Nevertheless, it depends on the organisation's capability in regards to the policy, approach, human resources, and outsourcing strategies.

\section{Asset Misappropriation}

Asset misappropriation is a fraudulent act in which the perpetrator deceit to steal or misuse an organisation's resources. A particular asset of the organisation is taken to benefit the individuals committing the fraud. ACFE reported in their survey, "Report to the Nation on 2020 Global Study on Occupational Fraud and Abuse", asset misappropriation schemes were the most common type of occupational fraud.

Occupational fraud can be defined as "...the use of one's occupation for personal enrichment through the deliberate misuse or misapplication of the employing organisation's resources or assets" (ACFE, 2020, p.86). Other than the misappropriation of assets, there are two other occupational fraud schemes: financial statement fraud and corruption.

Asset misappropriation is divided into two main categories, namely (1) Cash theft that consists of theft of cash on hand, theft of cash receipt, and fraudulent disbursement, and (2) Inventory and all other assets that include misused and larceny (Wells, 2017). A study by Ab Majid et al. (2010) found that misuse of an asset, such as vehicles and Internet connection, computer equipment, stationery, and telephone usage are the most likely assets to be abused in the government sector under non-cash theft. The study also envisages that misappropriation of assets would increase in the future. Thus, an anti-fraud arrangement needs to be taken to address this problem, which demands organisational commitment and staff commitment to foster an ethical corporate environment (Majid et al., 2016).

The government of Malaysia has invested time, money, and effort monitoring and countering fraud. For example, in 2018, the government had established a Governance Integrity and Anti-Corruption (GIAC) centre to coordinate and monitor all activities related to governance, integrity, and anti-corruption in Malaysia. The GIAC has introduced National Anti-Corruption Plan (NACP) 2019-2023 as one of the government's initiatives to set a practical goal focusing on initiatives to be taken by both government and private institutions to combat corruption, enhance integrity, and implement governance practice (Abas et al., 2019).

The objective of NACP is to address the deterrence of asset misappropriation. The 
NACP has listed a few strategies on asset misappropriation. For instance, strategy 1.1.9 emphasises the insertion of legal provisions on using the government's assets to promote the election of any candidate or political party as an offence under the Election Offences Act 1954. This strategy is issued to safeguard the government asset from being misuse for unofficial purposes. Furthermore, strategy 2.3.3 highlighted strengthening the mechanism in enforcing mandatory job rotation for public servants in high-risk position. The job rotation is Occupational Fraud Prevention Mechanisms (Shanikat et al., 2014) because employees who committed fraud tend to be continuously working the same job to mask their fraud. However, when the employee is compelled to do another task, the employee will no longer conceal their fraudulent activities.

\section{Training Policy}

Training policy plays a vital role in ensuring growth and progress in the organisation to ensure employees have the right knowledge, expertise, and skills to carry out their assigned duties. Campbell and Kuncel (2002) defined training as a planned intervention designed to enhance individual job performance determinants. According to Tziner et al. (1991), the main objective of the training is to assist individuals in creating aptitudes and abilities that, when connected to work, can improve their normal work execution in their current work. Thus, organisations are recommended to provide adequate training to enhance employees' knowledge to manage their assets better (Backer \& Yusoff, 2015). This suggestion indicates the value of training, and it is imperative to decide its relative need compared to other components. This is support by Hipkin (2001), who stated that knowledge is fundamental to gain higher-level benefits in managing assets.

Abdullah et al. (2011) asserted that employees with specific skills, adequate experience, and sound technical knowledge are the most valuable assets of the organisation, fundamental and noteworthy in AM practices. The notion is supported by Shah et al. (2017), and Too (2012), who suggested that employees could improve their capability to manage assets through good training programmes, and they can exploit and utilise technologies for monitoring assets condition.

Training policy is a set of guidelines and requirements for transferring knowledge systematically and precisely to add knowledge and skills to meet the organisation's current needs and demands (Public Sector Human Resource Policy, 2005). It enables the organisations to plan on an ongoing investment for their employees and build competencies (Jackson et al., 2003), which benefits both the employees and organisations. 


\section{Relationship between Maintenance Practice, Asset Misappropriation, Training Policy, and Asset Management Performance}

The framework of factors affecting asset management performance is built to propose the variables that directly impact government agencies' asset management performance. Previous literature found that maintenance practice (Al Marzooqi et al., 2019; Cholasuke et al., 2004), training policy (Al Marzooqi et al., 2019), and asset misappropriation (Effiok et al., 2012; Majid et al., 2014) have significant relationships with asset management performance.

\section{Relationship between Maintenance Practice and Asset Management Performance}

A comprehensive maintenance practice contributes positively to an organisation's overall strategic objectives (Muchiri et al., 2011). Poor maintenance will hinder value addition, delay the return of assets, and disrupt the business strategy. However, most managers regard maintenance as a financial burden (Sherwin, 2000) because maintenance involves enormous costs to the organisation. To address this issue, most organisations choose to maximise the available assets' performance by implementing strategic maintenance planning whereby the maintenance is conducted based on the necessity to avoid higher costs in the future due to equipment damage (Eti et al., 2006).

Past literature has acknowledged the relationships among maintenance management, performance, and profitability (Al Marzooqi et al., 2019; El-Akruti \& Dwight, 2013; Kutucuoglu \& Hamali, 2001). This is consistent with Chanter and Swallow (2007); they claimed that when maintenance work is not carried out effectively, user efficiency will be impaired, leading to poor organisational performance and profit loss. Maintenance management and government assets' effectiveness are critical factors in ensuring all government agencies are working to achieve their respective public interest objectives (Cholasuke et al., 2004).

\section{Relationship between Asset Misappropriation and Asset Management Performance}

Asset misappropriation has diverted finite resources and compromises the government's ability to deliver services and achieve intended outcomes (Public \& Fraud, 2020). In this context, AM cannot be carried out effectively due to resource constrain. Insufficient money causes assets maintenance disrupted, and obsolete assets cannot be replaced; thus, the public cannot get quality services as needed. Majid et al. (2014) posited that reducing available resources would negatively affect the organisation's ability to achieve its goals set out in its vision, mission, and policy statements.

Asset misappropriation has a significant negative association with organisational performance (Effiok et al., 2012) because its resources are disrupted, and productivity is affected. Asset misappropriation also caused many parties to suffer (Nia \& Said, 2015). The perpetrator will be penalised and may lose their jobs if caught. The government agencies are also suffering from a lack of resources and constraints in delivering services to people, impacting government agencies' reputation and credibility. Consequently, people do not get quality service from government agencies. Similarly, for this study, asset misappropriation is predicted to reduce AM performance in government agencies.

\section{Relationship between Training Policy and Asset Management Performance}

Training contributes to a culture of improving, learning, increasing employees' efficiency, and eventually increasing organisational performance (Kamoche \& Mueller, 1998). Therefore, organisations should develop appropriate training programmes to improve employees' knowledge, skills, and abilities. Furthermore, sufficient knowledge and skills are vital for 
managing assets because AM deals with various fields and often faces complex uncertainties (Schuman \& Brent, 2005), such as technical and financial aspects. Thus, training can enhance employees' knowledge to promote better AM practice (Norhidayah et al., 2015). Lack of knowledge, incompetence, and unskilled employees may affect the quality of services delivered (Salah, 2016).

A study by Olaniyan and Ojo (2008), and Naqvi and Khan (2013) revealed that training has a significant positive relationship with organisational performance. The positive impact between training and organisational performance is that increased employees' skill, knowledge, and ability gained from training affects employees' commitment to the organisation, resulting in better productivity (Daniel, 2018). Therefore, it is necessary to improve and apply training as part of organisational agendas to achieve organisational objectives.

Nevertheless, several studies have also found that training did not directly influence organisational performance; other factors have mediated it, such as work climate (Gelade \& Ivery, 2003) and organisational learning (Martínez-Ferrero \& García-Sánchez, 2017). Based on previous literature, training is imperative to enhance employees' knowledge and abilities, leading to better asset management performance.

\section{Conclusion}

This study analysed the relevant literature to understand better the asset management landscape and factors affecting asset management performance. The literature review section also discusses asset management's significance and an overview of asset management practice in Malaysia. The government is committed to review and enhance the quality of AM to ensure it is managed in a systematic, holistic, and sustainable manner; hence, the issuing of policies and procedures regarding asset management since 1967. The importance of asset management has also been discussed in the literature review to explain why the government needs to manage assets effectively. This study is expected to help researchers and practitioners improve asset management performance by understanding and identifying the factors affecting asset management performance.

This study contributes to the literature by adding a new conceptualization to fill the literature gap highlighted in section 2.1.2. In addition, this paper can assist the government in implementing a systemic and comprehensive approach to asset management framework that reflects strategic execution elements highlighted: maintenance practice, assets misappropriation, and training policy in the current guidelines. Finally, implementing good maintenance practices, preventing asset misappropriation practices, and strengthening training policies in the AM framework can reduce auditors' repeated issues and enhance public money management credibility.

The study is based on the Auditors-General Report and the previous literature reviewed to fit the proposed concept. There are some limitations to this study. Firstly, the study only covered three factors affecting AM performance: maintenance practice, assets misappropriation, and training policy; future studies should explore more factors that affect AM performance. Secondly, this paper did not test the validity of the relationship on the variables of the study. Thus, In the future, this study would empirically validate the relationship to provide a better statistical standing of the variables used. 


\section{References}

Ab Majid, R., Mohamed, N., Abdullah, A., \& Mahmud, Z. (2010). An exploratory study on the possibility of misappropriation of assets occurring in a local authority. CSSR $2010-2010$ International Conference on Science and Social Research, Cssr, 36-41. https://doi.org/10.1109/CSSR.2010.5773802

Abdullah, F. A., \& Muhammad, K. (2020). Factors influencing valuation accuracy of PPE in public sector FS: Accountants' perspective. Journal of Critical Reviews, 7(19), 459-471.

Abdullah, S., \& Razak, A. A. (2011). The characteristics of real estate assets management practice in the Malaysian Federal Government. Journal of Corporate Real Estate, 13(1), 16-35. https://doi.org/10.1108/14630011111120323

Al Marzooqi, F. A., Hussain, M., \& Ahmad, S. Z. (2019). Performance of physical asset management using the analytic hierarchy process. Property Management, 37(3), 327345. https://doi.org/ 10.1108/PM-07-2018-0039

Alfatih, S., Leong, M. ., \& Hee, L. M. (2015). Definition of engineering asset management: a review. Applied Mechanics and Materials (Vol. 773, pp. 794-798). Trans Tech Publications Ltd. https://doi.org/10.4028/ www.scientific.net/amm.773-774.794

Amadi-Echendu, J. E. (2004). Managing physical assets is a paradigm shift from maintenance. Proceedings of Engineering Management Conference, IEEE International, 3, 1156-1160. https://doi.org/10.1109/iemc.2004.1408874

Amadi-Echendu, J., Willett, R., Brown, K., \& Yang, B. (2010). What is engineering asset management? In Definitions, Concepts and Scope of Engineering Asset Management (pp. 3-16). Springer London.

Association of Certified Fraud Examiners (ACFE). (2020). Report to the nations on occupational fraud and abuse: 2020 global fraud study. Acfe, 88.

Buang, A. (2011). "Public asset management in Malaysia - An audit perspective." At the 1st World Congress and Exhibition Infrastructure Asset Management PWTC Kuala Lumpur, February, 1-7.

Campbell, J. D., \& Reyes, J. V. (2014). Uptime: Strategies for Excellence in Maintenance Management. In Vascular (3rd ed., Issue January 2010). CRC Press Taylor \& Francis Group6000 Broken Sound Parkway NW, Suite 300 Boca Raton, FL 33487-2742.

Campbell, J. P., \& Kuncel, N. R. (2002). Individual and team training. In Handbook of Industrial, Work and Organizational Psychology (Issue January 2001, pp. 278-312).

Chanter, B., \& Swallow, P. (2007). Building Maintenance Management (Second Edi). Oxford: Blackwell.

Cholasuke, C., Bhardwa, R., \& Antony, J. (2004). The status of maintenance management in UK manufacturing organisations: Results from a pilot survey. Journal of Quality in Maintenance Engineering, 10(1), 5-15. https://doi.org/10.1108/13552510410526820

Daniel, C. O. (2018). Effects of Training on Organizational Performance. Asian Journal of Business and Management, 6(5), 58-67. https://doi.org/10.24203/ajbm.v6i5.5489

Effiok, S. O., Ojong, C. M., \& Usang, O. U. E. (2012). the Implication of Occupational Fraud and Financial Abuse on the Performance of Companies in Nigeria. Interdisciplinary Journal of Contemporary Research in Business, 4(7), 516-533.

http://search.ebscohost.com/login.aspx?direct=

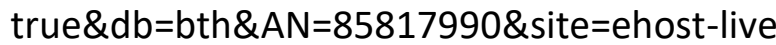

El-Akruti, K., \& Dwight, R. (2013). A framework for the engineering asset management system. Journal of Quality in Maintenance Engineering, 19(4), 398-412.

https://doi.org/10.1108/JQME-01-2012-0002 
Elnaga, A., \& Imran, A. (2013). The effect of training on employee performance. European Journal of Business and Management, 5(4), 137-147.

Eti, M. C., Ogaji, S. O. T., \& Probert, S. D. (2006). Reducing the cost of preventive maintenance ( PM ) through adopting a proactive reliability-focused culture. Applied Energy, 83(11), 1235-1248.

Fouladgar, M. M., Yazdani-Chamzini, A., Lashgari, A., Zavadskas, E. K., \& Turskis, Z. (2012). Maintenance strategy selection using AHP and COPRAS under fuzzy environment. International Journal of Strategic Property Management, 16(1), 85-104. https://doi.org/10.3846/1648715 X.2012.666657

Garramone, M., Moretti, N., Scaioni, M., Ellul, C., Re Cecconi, F., \& Dejaco, M. C. (2020). BIM and GIS Integration for Infrastructure Asset Management: A Bibliometric Analysis. ISPRS Annals of the Photogrammetry, Remote Sensing and Spatial Information Sciences, 6(4/W1), 77-84. https://doi.org/10.5194/isprs-annals-VI-4-W1-2020-77-2020

Gelade, G. A., \& Ivery, M. (2003). The Impact of Human Resource Management and Work Climate. Personnel Psychology, 56(2), 383-404.

Hanis, M. H., Trigunarsyah, B., \& Susilawati, C. (2010). Elements of Public Asset Management Framework for Local Governments in Developing Countries. 8th International Conference on Construction and Real Estate Management (ICCREM 2010), 1-3 December 2010, Royal on the Park Hotel, Brisbane. https://doi.org/10.13140/2.1.1056.3840

Haron, R., Mohamed, N., \& Paino, H. (2015). Misappropriation of assets: A decepticon of leakages in Malaysian public sector. Proceedings of the International Conference on Accounting Studies (Icas) 2015, October 2013, 70-77.

Hastings, N. A. J. (2015). Physical asset management: With an introduction to ISO55000. In Springer. https://doi.org/10.1007/978-3-319-14777-2

Hipkin, I. (2001). Knowledge and IS implementation: Case studies in physical asset management. International Journal of Operations and Production Management, 21(10), 1358-1380. https://doi.org/10.1108/01443570110404763

Ismail, A. H., binti Saidin, N. F., Saad, S., Dangi, M. R. M., \& Johari, R. J. (2019). Asset management practices: Malaysian government departments perspective. International Journal of Modern Trends in Business Research (IJMTBR), 2(8), 23-40.

Jackson S.E., DeNisi A., \& Hitt M.A. (2003). Managing Knowledge for Sustained Competitive Advantage: Designing Strategies for Effective Human Resource Management. John Wiley and Sons.

Jooste, J. L., \& Page, D. C. (2004). A Performance Management Model for Physical Asset Management. The South African Journal of Industrial Engineering, 15(2). https://doi.org/10.7166/15-2-204

Kaganova, O., \& Amoils, J. M. (2020). Central government property asset management: a review of international changes. Journal of Corporate Real Estate. https://doi.org/10.1108/JCRE-09-2019-0038

Kamoche, K., \& Mueller, F. (1998). Human resource management and the appropriatelearning perspective. Human Relations, 51(8), 1033-1060.

Kannan, H. K. (2018, October 8). Works Ministry calls for review of Government Asset Management Policy. The New Straits Times Online.

https://www.nst.com.my/news/nation/2018/10/419039/ works-ministry-calls-reviewgovernment-asset-management-policy

Kirubakaran, B., \& Ilangkumaran, M. (2016). Selection of optimum maintenance strategy based on FAHP integrated with GRA-TOPSIS. Annals of Operations Research, 245(1-2), 
285-313. https://doi.org/10.1007/s10479-014-1775-3

Kriege, L. K., Jooste, W. J. L., \& Vlok, P. J. (2016). A framework for establishing a human asset register for the improved management of people in physical asset management. South African Journal of Industrial Engineering, 27(4), 77-89. https://doi.org/10.7166/27-41549

Kutucuoglu, K. Y., \& Hamali, J. (2001). A framework for managing maintenance using performance measurement systems. International Journal of Operations \& Production Management, 21(1), 173-194.

Laue, M., Brown, K., Scherrer, P., \& Keast, R. (2014). Integrated strategic asset management: Frameworks and dimensions. Third International Engineering Systems Symposium CESUN 2012, Delft University of Technology, 24(December), 75-87.

https://doi.org/10.1007/978-3-319-02493-6_6

Lebas, M., \& Euske, K. (2007). 5 A conceptual and operational delineation of performance. In Business Performance Measurement: Theories and Practice (p. 65). https://doi.org/10.1017/СВ09780511805097.008

Majid, R. A., Basri, S. A., Mohamed, N., \& Ahmad, K. (2016). The commitment of local authorities in building fortress against misappropriation of assets. Management \& Accounting Review (MAR), 15(2), 1-11.

Majid, R. A., Mohamed, N., Haron, R., Omar, N. B., \& Jomitin, B. (2014). Misappropriation of Assets in Local Authorities: A Challenge to Good Governance. Procedia - Social and Behavioral Sciences, 164(August), 345-350. https://doi.org/10.1016/j.sbspro.2014.11.086

Martínez-Ferrero, J., \& García-Sánchez, I. M. (2017). Coercive, normative and mimetic isomorphism as determinants of the voluntary assurance of sustainability reports. International Business Review, 26(1), 102-118. https://doi.org/10.1016/j.ibusrev.2016.05.009

Mastroianni, E., Lancaster, J., Korkmann, B., Opdyke, A., \& Beitelmal, W. (2021). Mitigating infrastructure disaster losses through asset management practices in the Middle East and North Africa region. International Journal of Disaster Risk Reduction, 53(July 2020), 102011. https://doi.org/10.1016/j.ijdrr.2020.102011

Mazlan, R. M. R., \& Mohammed, M. A. H. (2008). Identifying maintenance issues in Malaysia. Association Of Schools Of Construction Of Southern Africa (ASOCSA), The Third Built Environment International Conference, At The Westin Grand Cape Town Arabella Quays, Cape Town, October, 13.

Mihaiu, D. M., Opreana, A., \& Cristescu, M. P. (2010). Efficiency, effectiveness and performance of the public sector. Romanian Journal of Economic Forecasting, 13(4), 132-147.

Backer, M. A. B. M. A., \& Yusoff, W. Z. W. (2015). A review of asset management practice in Malaysian Local Governments. Proceedings of the 25th International Business Information Management Association Conference - Innovation Vision 2020: From Regional Development Sustainability to Global Economic Growth, IBIMA 2015, January, 3577-3582.

Muchiri, P., Pintelon, L., Gelders, L., \& Martin, H. (2011). Development of maintenance function performance measurement framework and indicators. International Journal of Production Economics, 131(1), 295-302. https://doi.org/10.1016/j.ijpe.2010.04.039

Naief, A. (2017). Physical asset management practices in the Saudi public sector. Built Environment Project and Asset Management, 7(1), 19-31. 
https://doi.org/10.1108/BEPAM-12-2015-0070

Naief, A. (2018). A theoretical framework for physical asset management practices. Facilities, 36(3-4), 135-150. https://doi.org/10.1108/F-02-2016-0025

Neely, A. (2007). Measuring performance: The operations management perspective. In Business Performance Measurement: Unifying theories and integrating practice (Second Edi). Cambridge University Press. https://doi.org/10.1017/СBO9780511805097.005

Nel, C. B. H., \& Jooste, W. J. L. (2016). A technologically-driven asset management approach to managing physical assets - a literature review and research agenda for 'smart' asset management. South African Journal of Industrial Engineering, 27(4), 50-65. https://doi.org/10.7166/27-4-1478

Nia, E. H., \& Said, J. (2015). Assessing fraud risk factors of assets misappropriation: Evidences from Iranian Banks. Procedia Economics and Finance, 31(15), 919-924. https://doi.org/10.1016/S2212-5671(15)01194-6

Norhidayah, M. Y., Khadijah, H., Maryanti, M. R., Ainur Zaireen, Z., Maslinda, A. L., Razali, M. N., ... \& Siti Radiaton Adawiyah, Z. (2015). Local authorities challenges in the implementation of maintenance and operation blueprint. Jurnal Teknologi, 73(5).

Olaniyan, D. A., \& Ojo, L. B. (2008). Staff training and development: A vital tool for organisational effectiveness. European Journal of Scientific Research, 24(3), 326-331.

Ratnayake, R. C., \& Markeset, T. (2010). Technical integrity management: measuring HSE awareness using AHP in selecting a maintenance strategy. Journal of Quality in Maintenance Engineering.16(1), 44-63.

Rasolonjatovo, H., Lande, E., \& Harison, V. (2015). Active asset management: feasibility in Malagasy municipalities. Public Money and Management, 35(6), 417-422. https://doi.org/10.1080/09540962.2015.1083686

Salah, M. R. A. (2016). The impact of training and development on employees performance and productivity. International Journal of Management Sciences and Business Research, 05(07), 36-57. https://doi.org/10.4172/2315-7844.1000160

Sanjaya, K. E., \& Utama, M. S. (2020). Asset management performance in the government of Jembrana Bali Regency. International Research Journal of Management, IT \& Social Sciences, 7(4), 24-35.

Sara, I. M., Saputra, K. A. K., \& Utama, I. W. K. J. (2021). The Effects of Strategic Planning, Human Resource and Asset Management on Economic Productivity: A Case Study in Indonesia. Journal of Asian Finance, Economics and Business, 8(4), 381-389. https://doi.org/10.13106/jafeb.2021.vol8.no4.0381

Schraven, D., Hartmann, A., \& Dewulf, G. (2011). Effectiveness of infrastructure asset management: Challenges for public agencies. Built Environment Project and Asset Management, 1(1), 61-74. https://doi.org/10.1108/20441241111143786

Schuman, C. A., \& Brent, A. C. (2005). Asset life cycle management: Towards improving physical asset performance in the process industry. International Journal of Operations and Production Management, 25(6), 566-579. https://doi.org/10.1108/01443570510599728

Shah, R., McMann, O., \& Borthwick, F. (2017). Challenges and prospects of applying asset management principles to highway maintenance: A case study of the UK. Transportation Research Part A: Policy and Practice, 97, 231-243.

https://doi.org/10.1016/j.tra.2017.01.011

Naqvi, S. M. H., \& Khan, M. A. (2013). Employees Training and Organizational Performance: Mediation by Employees Performance. Interdisciplinary Journal of Contemporary 
Research In Business, 5(4) 490-503.

Shanikat, M., Al-Farah, A., \& Tariq, D. (2014). Occupational fraud prevention mechanisms: Jordanian companies experience. Research Journal of Finance and Accounting, 5(1), 8492. www.iiste.org

Sherwin, D. (2000). A review of overall models for maintenance management. Journal of Quality in Maintenance Engineering, 6(3), 138-164.

https://doi.org/10.1108/13552510010341171

Too, E. (2012). Infrastructure asset: Developing maintenance management capability. Facilities, 30(5-6), 234-253. https://doi.org/10.1108/02632771211208503

Too, E. G. (2010). A framework for strategic infrastructure asset management. Engineering Asset Management Review, 1, 31-62. https://doi.org/10.1007/978-1-84996-178-3_3

Tziner, A., Haccoun, R. R., \& Kadish, A. (1991). Personal and situational characteristics of transfer of training improvement strategies. Journal of Occupational Psychology, 64(2), 167-177.

Wells, J. T. (2017). Occupational fraud and abuse; The big picture. In Corporate Fraud Handbook (pp. 366-379). John Wiley \& Sons. https://doi.org/10.1002/9781119351962.ch14

Wijnia, Y. (2016). Towards Quantification of Asset Management Optimality. Proceedings of the 10th World Congress on Engineering Asset Management (WCEAM,2015), Wceam 2015, 663-670. https://doi.org/10.1007/978-3-319-27064-7 